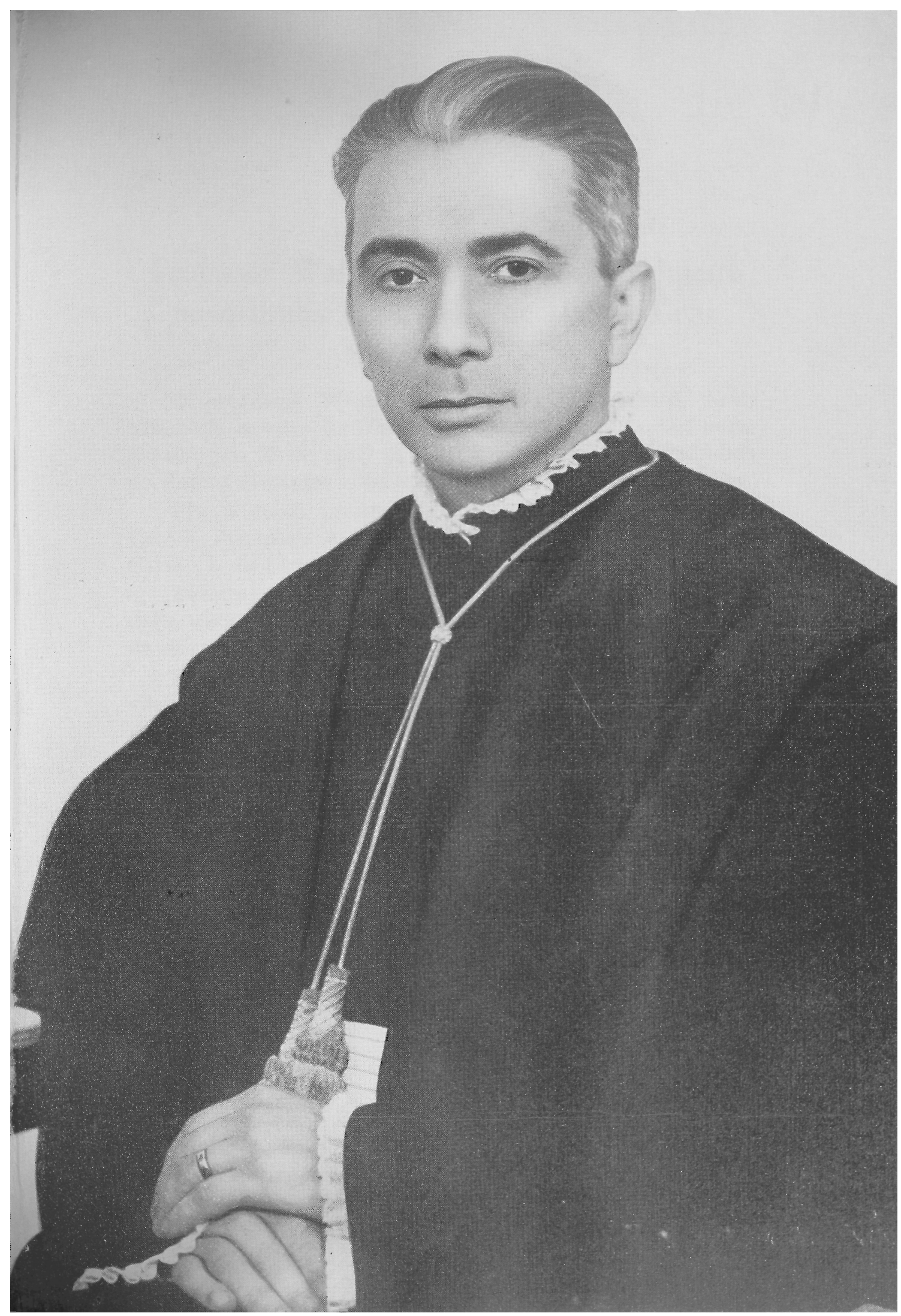




\section{Professor Washington de Barros Monteiro novo titular de Cátedra de Direito Civil}

O professor Washington de Barros Monteiro, novo titular da cadeira de Direito Civil, nasceu em Areias, neste Estado, aos 22 de abril de 1910, sendo filho do dr. Phidias de Barros Monteiro e de d. Erotides de Carvalho Monteiro.

Fêz o curso primário nos Grupos Escolares de São Carlos, Penápolis e Assis e o secundário, no Ginásio do Carmo e no Liceu Nacional Rio Branco.

Terminados os preparatórios, matriculou-se na Faculdade de Direito de São Paulo, onde recebeu grau aos 3 de setembro de 1931.

Tendo ingressado, em seguida, na carreira policial, serviu sucessivamente nas delegacias de Itatinga e de Ordem Política, bem como no Gabinete de Investigações e nas delegacias de Cajurú e de São José do Rio Preto.

Durante sua permanência na Capital do Estado, cursou também a Escola de Polícia (1934), então obtendo o prêmio "Mário Guimarães".

Classificado em primeiro lugar no concurso para juiz substituto, foi nomeado, em dezembro de 1935, para o Décimo Distrito Judicial, com sede em São José do Rio Preto.

Em 1939, foi nomeado juiz de direito da comarca de Presidente Wenceslau (primeira entrância), sendo em 1940 promovido para Barretos (segunda entrância) e em 1945 para Itapetininga (terceira entrância).

Nesse mesmo ano foi novamente promovido para a $1 .^{\mathrm{a}}$ Vara da Família e Sucessões, da Capital (quarta entrância), onde permaneceu até 1951, quando foi nomeado juiz do Tribunal de Alçada, então criado. 
Nesse colégio judiciário exerceu por duas vêzes a respectiva presidência (biênios 1952/1953 e 1956/1957). Em fevereiro de 1959, foi investido no grau de desembargador do Tribunal de Justiça, sendo, ato continuo, pôsto em disponibilidade, ex vi do art. 97 do Dec. 123, de 10-11-1892.

Entrementes, exerceu igualmente o cargo de juiz do Tribunal Regional Eleitoral, cargo em que foi reconduzido por uma vez, na forma da lei.

Em 1949, foi contratado para reger uma das cadeiras de Direito Civil da Faculdade Paulista de Direito, da Pontifícia Universidade Católica de São Paulo e nesse magistério se mantém até à presente data.

Publicou o "Curso de Direito Civil", de que já saíram seis volumes: Direito de Família (presentemente na quarta edição), Direito das Coisas (em terceira edição), Direito das Obrigações - $2 .^{\mathrm{a}}$ parte (segunda edição), Parte Geral, (segunda edição) e Direito das Obrigações - 1. a parte.

Tem ainda vários trabalhos publicados em revistas especializadas, notadamente "Dos Contratos Preliminares", na Revista Forense, vol. 173, pág. 489, e do "Recurso Extraordinário", em Justitia, vol. 21, pág. 22.

Com a vaga decorrente da aposentadoria do professor Alvino Lima, submeteu-se êle a concurso, tendo apresentado uma dissertação "Das Modalidades das Obrigações". A comissão examinadora, constituída dos professôres Vicente Ráo e Jorge Americano (de São Paulo), de Orlando Gomes (da Bahia), de Caio Mário da Silva Pereira (de Belo Horizonte) e de Miguel Maria de Serpa Lopes (de Niterói), considerou-o habilitado.

Aprovada a indicação, foi êle nomeado pelo Govêrno do Estado, tendo tomado posse aos 30 de dezembro de 1959, em sessão solene da Congregação desta Faculdade.

Introduzido no recinto da Congregação pelos Exmos. Srs. Professôres Cardoso de Mello Neto, Mário Masagão e Miguel Reale foi saudado pelo Prof. Honório Monteiro. 


\section{Discurso do Prof. Washington de Barros Monteiro}

Após a saudação do Prof. Honório Monteiro, disse o Prof. Washington de Barros Monteiro as seguintes palavras:

"Disse StendHal que experimentara uma espécie de sentimento religioso ao escrever a primeira frase da vida de Napoleão. Sinto-me igualmente dominado pela mesma emoção ao redigir e pronunciar estas primeiras palavras como professor da Faculdade de Direito da Universidade de São Paulo.

Não pode haver, realmente, maior honra que a de ensinar na própria escola em que se foi aluno. Essa honra adquire mais vivo colorido, quando se trata desta Faculdade, veneranda e secular, que, em cada um de seus fillhos espirituais, no fundo de seus corações, forma a nascente obscura, de onde brotam suas aspirações, seus sonhos e as fontes de suas vidas.

Nesta casa, em que me formei e em que se formou meu pai, se escreve a própria história de São Paulo, nela se vislumbra a própria face, luminosa e comovedora, de nossa pátria.

Suas luzes exercem estranho e fantástico poder. Sua essência misteriosa, humanamente indefinivel, mistura-se às nossas vidas e aos nossos sentimentos, dando-nos um ponto de apoio, dotado de valor fecundo e de duração eterna.

Dos grandes mestres, que aqui viveram, lutaram e sofreram, resta ainda surpreendente radiação, algo que não morre, e que misteriosamente influi naqueles que lhes sucedem, a fôrça de seu exemplo. Como diz Edmond Jaloux, "as árvores se renovam e nós passamos. E, portanto, se as árvores persistem, as fôlhas caem, e se nós morremos, as idéias permanecem". Só peço a Deus que nesta casa possa seguir o exempla dêsses mestres e não deslustrar-lhes as tradições.

Permitam os eminentes mestres que me ouvem lhes devasse meu coração e lhes narre, com verdade e com cla- 
reza, o que em meu íntimo se passa, nesta hora que verdadeiramente representa o fim e o resumo de tôdas as minhas aspirações.

Começo por uma breve história. Certa vêz, há muitos anos, encontrei-me com alguém que me dizia: "tôda a minha existência passei em meu vale natal, circundado de montanhas. Meu mundo encerrava-se naquele pequeno espaço, delimitado pelas serras. Um dia, porém, galguei-lhes as encostas e verifiquei que o mundo não se restringia aquele vale, em que até então vivera minha vida. Decidime desde logo e parti".

Eu também, ilustres professôres, como aquêle personagem de minha história, vivia encerrado nas funções judiciárias, que, por irresistível vocação, elegera na juventude, Não imaginava existir outro mundo. Bastavam-me suas alegrias e seus desencantos, suas flôres e seus espinhos. Afinal, era um mundo plano, liso, sem marcos, sem acidentes, mas tranqüilo e feliz.

Certo dia, no entanto, movido por convite do ilustre professor Agostinho Alvim, diretor da Faculdade Paulista de Direito e cujo nome declino com admiração e amizade, principiei a reger, naquele estabelecimento de ensino, uma de suas cadeiras de Direito Civil.

Descobri então, surpreendido, que o mundo não se esgotava naquelas remansosas paragens, em que até então me movimentara. Outras regiões, desconhecidas, fascinantes e misteriosas, descortinei à minha frente: o magistério superior, a comunicação intelectual entre professôres e alunos, a formação espiritual dêstes, numa palavra, ser-lhes o iniciador, o mentor de seus estudos.

$\mathrm{Na}$ minha vida interior comecei então a alimentar (majore pennas nido), a suprema esperança de vir um dia para esta Faculdade. Vozes amigas, de amigos diletos, estimularam-me e decidiram-me.

Bem sabia quão árdua seria a luta. A marcha era longa e nela nunca se pode estar certo de chegar ao ponto de destino. A perspectiva dos lances a afrontar, das fadigas a vencer e dos transes a suportar, retinha-me indeciso. 
Resolvi-me, porém, e encetei a caminhada. Uma vez traçado o caminho já se não pode deixar de segui-lo. E agora, que para trás ficaram tôdas as dificuldades, não posso deixar de pensar, com Graça Aranha: quando no meio das ondas e dos ventos, o espetáculo do oceano enchia-me a alma de terror, porém, agora, depois de atravessado, olho-o de longe e as crispações das vagas são como um leve sorriso.

Como é bom imaginar-se uma coisa e depois ela acontecer realmente. Aqui me encontro, porém, com a maior humildade. Aproximo-me desta Congregação, sem dúvida uma das mais brilhantes e das mais notáveis que regista a história da Faculdade de Direito de São Paulo, tão notável e tão brilhante como as que mais o foram no seu passado de glórias, com a alegria de encontrar antigos mestres, cujas lições com carinho guardo, como Brás Arruda e Vicente Ráo, e velhos condiscípulos do mesmo período academico, como os professôres Gama e Silva, que preside a esta cerimônia, Miguel Reale, Bueno Vidigal e Joaquim Canuto Mendes de Almeida. Constitui para mim inexcedível honra conviver com êsses e demais mestres desta Casa, cujas lições se ouvem, não só em São Paulo, como em todo o Brasil.

Aqui venho substituir o professor Alvino Lima, a quem presto tôdas as minhas homenagens. Trata-se de mestre consumado, que abriu caminho pelo seu próprio esfôrço e que, nesta casa, se notabilizou pela sua dedicação ao ensino, tornando-se um de seus mestres mais eficientes e mais dignos.

Cabe-me ainda aos de minha família dirigir uma palavra de afeto e de gratidão, pela assistência e confôrto que me deram. Todos, mãe e irmãos, espôsa e filhas, acompanharam-me passo a passo, compartilhando comigo de tôdas as apreensões, comigo sofrendo tôdas as agruras. A êles pertence também êste dia de festa. Não fôra sua solidariedade, não lhes sentisse a pressão de seus suaves afetos, nunca chegaria a esta consagradora investidura. Só lamento a ausência de meu pai, que há poucos meses partiu, inteligência privilegiada, espírito de escol, de quem na 
mocidade, muitas vêzes, ouvi o propósito de defender tese, mas que nunca teve a oportunidade que êle merecia pelo seu talento.

Não devo esquecer-me igualmente dos caros colegas de turma, que, numa perfeita comunhão de sentimentos, aqui estiveram durante tôdas as provas, dando-me, com o estímulo de sua presença, a fôrça de que carecia. A cada um em particular abraço neste instante, externando-lhes minha sincera gratidão e infinita amizade.

Uma palavra de reconhecimento devo ainda dizer aos queridos colegas da magistratura, notadamente aos do $\mathrm{E}$. Tribunal de Alçada, dos quais recebi, numa angustiosa vigília, o incentivo da sua confiança e da sua solidariedade.

Não me faltaram também os amigos, que me acompanharam com os seus conselhos e porque não dizê-lo, com as suas orações. Foram todos admiráveis e perfeitos. Mas não seria justo se não destacasse o professor José Amazonas, a cuja experiência, sabedoria e bondade muito devo.

Saint-Exupery, num de seus livros admiráveis, afirma que só, no vasto tribunal que um céu tempestuoso forma, o pilôto disputa seu aparelho a três divindades elementares, a montanha, a tempestade, o mar. Mais feliz, porém, pude contar com a prestimosa ajuda de todos, parentes e amigos, que, unidos pela mesma comunidade de afetos, me propiciaram esta hora feliz.

Ao caríssimo mestre e amigo, professor Honório Monteiro, desejo agradecer, por fim, as carinhosas palavras de amizade, proferidas nesta solenidade.

Vinculam-nos antigos laços de indestrutível afeto. Quando ainda modesto juiz de primeira instância, e êle Ministro da Justiça, lembrou-se de mim para o alto cargo de juiz do E. Tribunal Federal de Recursos.

Pouco depois, todavia, ao verificar que seu convite não era confirmado pelo Presidente da República, não teve dúvida em abandonar a pasta, bem como a do Trabalho, dando assim ao Brasil admirável exemplo de altivez, om- 
bridade e desprendimento, aliás, apanágio dos paulistas, no desempenho de tais investiduras. A Sua Excelência, pois, neste ensejo, rendo as minhas homenagens, bem como as expressões do meu imperecível reconhecimento.

Meus eminentes mestres: a Faculdade de Direito de São Paulo é a vinha de que todos os seus professôres são os ramos; ela representa o centro de cultura, de que constituem êstes os apóstolos. Templo, flama e poesia, é bem a alma mater, a que nos achamos, eterna e indissolùvelmente ligados, pelo espírito e pelo coração.

Permitam-me que me reuna a esta Congregação e a todos peço façam de mim um dos seus. Repetindo essa súplica, dirigida outrora por Anacarsis a Solon, desejo dizer-lhes que se infelizmente não posso prometer brilho e talento no exercício da cátedra, posso contudo prometer o mais intenso esfôrço e o mais decidido desejo de ser útil.

Assim renovo o solene compromisso há pouco firmado." 